\title{
Heat Treatment of Sintered Valve Seat Inserts
}

\author{
Maurilio Pereira Gomes $^{a} \mathbb{D}_{\text {, Igor Passos dos Santos }}^{a}$, Camila Pucci Couto ${ }^{a}$, Evandro Giuseppe Betini ${ }^{a}$, \\ Luis Augusto Mendes dos Reis ${ }^{a}$, Cristiano Stefano Mucsi ${ }^{a}$, Marco Antônio Colosio $^{b}$,
}

\section{Jesualdo Luiz, Rossi ${ }^{a}$}

\author{
anstituto de Pesquisas Energéticas e Nucleares - IPEN, Av. Prof. Lineu Prestes, 2242, 05.508-000, São \\ Paulo, SP, Brasil \\ ${ }^{b}$ General Motors Mercosul, Av. Goiás, 1805, 09.521-310, São Paulo, SP, Brasil
}

Received: January 26, 2018; Revised: June 10, 2018; Accepted: July 11, 2018

\begin{abstract}
The characterization of sintered valve seat inserts (VSIs) after being subjected to different heat treatment operations has been carried out. The VSIs were obtained from three different alloys by mixing iron powder with AISI M3:2, AISI M2 high-speed steels, and AISI D2 tool steel. After sintering, the VSI were quenched in air followed by double tempering at seven different temperatures. The cooling rate during air quenching was measured by means of a thermocouple type $\mathrm{k}$ attached to a data acquisition system. The characterization of the mechanical and physical properties of the VSIs was achieved by measuring relative density, apparent hardness and crush radial strength. The resulting microstructures for the sintered parts were interpreted using the isothermal and continuous cooling transformation diagrams for similar alloys. The VSI obtained with AISI M3:2 and AISI M2 high-speed steels after air quenching and double tempering at $600{ }^{\circ} \mathrm{C}$ showed the best results in terms of apparent hardness and crush radial strength.
\end{abstract}

Keywords: Powder metallurgy, High-speed steel, Valve seat insert, Heat treatment.

\section{Introduction}

Automobile engines have undergone substantial changes, which have resulted in increased performance, reduced fuel consumption and positive environmental impact ${ }^{1}$. The mechanical set responsible for partial sealing of the combustion chamber is composed of valve seat and valve seat insert (VSI), as shown in Fig. 1.

The VSI of the present work was first studied by Jesus Filho et al. ${ }^{2}$ using a mixture of iron powder and AISI M3:2 high-speed steel (HSS). This powder mixture was proposed as an alternative to replace cobalt and lead originally used in commercial VSI. Fujitsuka et $\mathrm{al}^{3}{ }^{3}$ and $\mathrm{Sakai}^{4}$ also proposed new components to substitute such elements. All these authors aimed to reduce the cost of the component (because cobalt was expensive at that time) and remove highly toxic lead. This led, Santos et al. ${ }^{5}$ to propose the use of two other steel powders, AISI M2 HSS and AISI D2 tool steel. The study was carried out to investigate the suitability of other steel powders as alternatives. The development of new compositions for the VSI is something that has already been carried out. For instance, Dalal et al. ${ }^{6}$ and Kano et al. ${ }^{7}$ proposed the use of copper alloys for the production of VSI. Such developments consider the use of materials with low density, high thermal conductivity, consistent mechanical and physical properties, and cost of materials ${ }^{8}$.

"e-mail: maurilio.pereira.gomes@gmail.com
The VSI for intake and exhaust of gases in the combustion chamber operates under severe conditions ${ }^{9,10}$. The worst case occurs in the exhaust stroke where the temperature at the valve seat and insert seat can reach $700{ }^{\circ} \mathrm{C}$ and $350{ }^{\circ} \mathrm{C}^{11-13}$, respectively. The use of powder metallurgy $(\mathrm{P} / \mathrm{M})$ components in the automobile industry has improved engine performance, as well as reduced its cost ${ }^{14,15}$. The use of either HSS or high-alloyed steels for sintered parts is a consolidated option for this application due to its good mechanical properties,

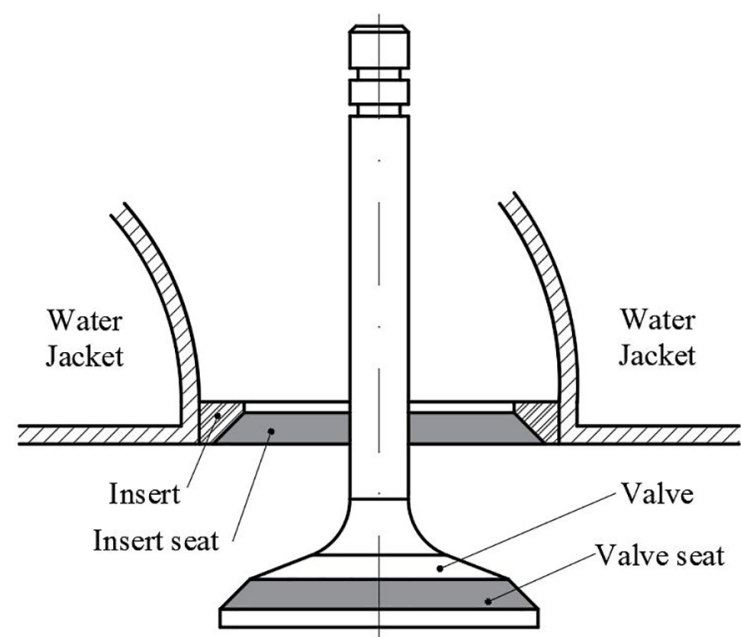

Figure 1. Schematic drawing indicating the valve and insert position in an internal combustion engine. 
corrosion resistance, high thermal conductivity and good machinability ${ }^{16-21}$.

The quenching or cooling of the workpiece from the austenitic zone transforms the austenite that forms at the high temperature to a harder martensitic microstructure ${ }^{22,23}$. The cooling rate, which must be controlled, is dictated by the chemical composition of each material ${ }^{24,25}$. Air quenching is the least drastic form of heat treatment a workpiece can be subjected to in comparison to other forms of quenching, i.e., water quenching and oil quenching. Only in thin cross sections would HSS cool rapidly enough to transform the majority of the microstructure into the desirable martensitic structure $^{25}$. Tempering, the final heat treatment step applied to steels, is accomplished by heating a martensitic or hardened material to some point below the transformation temperature $A_{1}$. This procedure defines the final structure and general properties of a hardened steel. The steps of austenitising and quenching are designed to generate the as-quenched microstructures that can be tailored by tempering to obtain the desired performance of a given steel ${ }^{26}$.

The kinetics aspects of phase transformation diagrams are as important as the equilibrium diagrams for heat-treating steels ${ }^{27}$. The increase of the cooling rates results in changes in the phase equilibrium conditions, therefore the usual transformation start conditions are changed ${ }^{28}$. The formation of non-equilibrium microstructures such as martensitic, bainitic, and fine perlitic structures are dependent on the austenitization parameters. These parameters are time, composition of the components and cooling temperature history ${ }^{29}$. The microstructural products are typically illustrated by transformation diagrams that show the temperature-time dependence of the microstructure formation process for a certain material $^{30}$.

The aim of the present work was to heat treat and characterize valve seat inserts obtained by means of $\mathrm{P} / \mathrm{M}$ technique with three different powder mixtures. The heat treatment involved air quenching and double tempering of all the components at seven different temperatures, ranging from $100^{\circ} \mathrm{C}$ to $700{ }^{\circ} \mathrm{C}$.

\section{Materials and Methods}

The nominal composition and the properties of the three different powders used in this work are presented in Table 1. The powder particle size distribution was determined by means of laser diffraction considering the theory of Fraunhofer and $\mathrm{Mie}^{31}$. The powder particle morphology was classified according to the model proposed by German ${ }^{31}$.

The chemical composition of each high-speed and tool steel shown in the previous table is shown in Table 2 in accordance with AISI standards ${ }^{32}$. The VSI final microstructure consisted of a mixture of each HSS and tool steel presented in Table 2 with others elements intentionally added as shown in Table 1 .

The powder mixtures are composed of iron, HSS type AISI M3:2, AISI M2 and tool steel AISI D2, niobium carbide, graphite, manganese sulphide and zinc stearate (which is used as an agglomerant to improve the compacted green density and reduce the die-wall friction). With the exception of copper, these powders were mixed in an intensive mixer at $1,715 \mathrm{rpm}$ for $300 \mathrm{~s}$; copper was later added to the VSI by metallic infiltration.

Green compacts were obtained from the compaction of the mixed powders in a double action Gasbarre hydraulic press (with a capacity of 100 tons) at a pressure of $700 \mathrm{MPa}$. From the compaction process, components having an annular format with dimensions of $32.5 \times 25.5 \times 5.9 \mathrm{~mm}^{3}$ were obtained. Copper rings were compacted separately and put over the green compacted insert during the sintering process. This technique is known as metallic infiltration, i.e., two compacts were pressed separately, one from the iron powder mixtures and the other from the copper powder, with one mounted on top of the other as shown in Fig. 2. According to Iervolino and Bulla ${ }^{33}$, the open and interconnected pores of a component can usually be infiltrated with copper or copper alloys, making it sealed against gases and liquids. At temperatures near $1,100^{\circ} \mathrm{C}$, the capillary pressure wicks the molten copper into the pores where it remains and solidifies

Table 1. Nominal composition of the three powder mixtures, powder particle size distribution obtained by laser diffraction, and particle morphology $^{31}$

\begin{tabular}{lcccccccc}
\hline \multirow{2}{*}{ Powder } & $\begin{array}{c}\text { Alloy 1, } \\
\text { mass \% }\end{array}$ & $\begin{array}{c}\text { Alloy 2, } \\
\text { mass \% }\end{array}$ & $\begin{array}{c}\text { Alloy 3, } \\
\text { mass } \%\end{array}$ & $\begin{array}{c}\mathbf{D}_{\mathbf{1 0},} \\
\mu \mathrm{m}\end{array}$ & $\begin{array}{c}\mathbf{D}_{\mathbf{5 0},} \\
\mu \mathrm{m}\end{array}$ & $\begin{array}{c}\mathbf{D}_{\mathbf{9 0},} \\
\mu \mathrm{m}\end{array}$ & $\begin{array}{c}\mathbf{D}_{\text {mean, }} \\
\mu \mathrm{m}\end{array}$ & $\begin{array}{c}\text { Morphology } \\
\text { AISI M3:2 }\end{array}$ \\
\hline 43.60 & - & - & 25.74 & 83.86 & 239.39 & 112.33 & Irregular \\
AISI M2 & - & 43.60 & - & 21.82 & 60.33 & 194.84 & 90.10 & Spherical \\
AISI D2 & - & - & 43.60 & 21.95 & 63.57 & 207.98 & 93.99 & Spherical \\
Fe & 43.60 & 43.60 & 43.60 & 45.63 & 106.28 & 317.59 & 139.83 & Irregular \\
MnS & 0.50 & 0.50 & 0.50 & 0.72 & 6.38 & 32.00 & 12.27 & Aggregate \\
NbC & 2.00 & 2.00 & 2.00 & 0.63 & 2.53 & 10.12 & 4.12 & Aggregate \\
C (graphite) & 0.30 & 0.30 & 0.30 & 10.41 & 34.30 & 61.57 & 35.51 & Flake \\
Cu (infiltration) & 10.00 & 10.00 & 10.00 & 10.26 & 24.26 & 48.88 & 27.25 & - \\
Zn stearate & 0.80 & 0.80 & 0.80 & - & - & - & - & - \\
\hline
\end{tabular}


Table 2. Chemical composition of the three powder mixtures carried out along this work in accordance with AISI standards ${ }^{32}$

\begin{tabular}{lccc}
\hline Element & $\begin{array}{c}\text { AISI M3:2, } \\
\text { mass \% }\end{array}$ & $\begin{array}{c}\text { AISI M2, } \\
\text { mass \% }\end{array}$ & $\begin{array}{c}\text { AISI D2, } \\
\text { mass \% }\end{array}$ \\
\hline $\mathrm{C}$ & $1.15-1.25$ & $0.95-1.05$ & $1.40-1.60$ \\
$\mathrm{Mn}$ & $0.15-0.40$ & $0.15-0.40$ & $0.60 \mathrm{max}$ \\
$\mathrm{Si}$ & $0.20-0.45$ & $0.20-0.45$ & $0.60 \mathrm{max}$ \\
$\mathrm{Cr}$ & $3.75-4.50$ & $3.75-4.50$ & $11.00-13.00$ \\
$\mathrm{Ni}$ & $0.30 \mathrm{max}$ & $0.30 \mathrm{max}$ & $0.30 \max$ \\
$\mathrm{Mo}$ & $4.75-6.50$ & $4.50-5.50$ & $0.70-1.20$ \\
$\mathrm{~W}$ & $5.00-6.75$ & $5.50-6.75$ & - \\
$\mathrm{V}$ & $2.75-3.75$ & $1.75-2.20$ & 1.10 max \\
$\mathrm{Fe}$ & Balance & Balance & Balance \\
\hline
\end{tabular}

- Nihil

to form a composite consisting of a steel skeleton filled with solidified copper ${ }^{34}$.

The sintering process was performed in a continuous industrial belt furnace that belongs to Group Combustol \& Metalpó ${ }^{35}$ under a hydrogen-based atmosphere $\left(90 \% \mathrm{H}_{2}+10 \% \mathrm{~N}_{2}\right)$. The green compact was pre-heated to $600{ }^{\circ} \mathrm{C}$ (using a heating rate of $0.3{ }^{\circ} \mathrm{C} / \mathrm{s}$ ) for $2,100 \mathrm{~s}$ to remove the zinc stearate. Then, the VSI was sintered at $1,150^{\circ} \mathrm{C}$ (heated at $0.2^{\circ} \mathrm{C} / \mathrm{s}$ ) for $2,400 \mathrm{~s}$. After that, all components were cooled to room temperature, whilst inside the belt furnace, at a cooling rate of $0.3^{\circ} \mathrm{C} / \mathrm{s}$.

After sintering, the VSI was heat treated with the support of a Quimis micro-processed laboratory muffle model Q-318M. A thermocouple type $\mathrm{k}$ was directly attached to the samples through mechanical interference adjustment ${ }^{36}$. In parallel, a data acquisition system was used to determine the thermal cycle during the heat treatment. In order to avoid decarburization, the inserts were put inside a steel box containing a mixture of $50 \% \mathrm{C}$ (graphite) and $50 \%$ $\mathrm{Al}_{2} \mathrm{O}_{3}$ (aluminum oxide). Thus, this powder mixture suffered the negative effects of the non-controlled atmosphere of the laboratory muffle rather than the components being heat-treated. Before the VSI were put inside the steel box, they were wrapped in a blick white sulphite drawing paper to avoid the direct contact of the samples with the graphite present in the protective powder mixture, thus preventing the carbonization of the components during heat treatment. The components were austenitized at $1,150^{\circ} \mathrm{C}$ (heated at a rate of $0.5^{\circ} \mathrm{C} / \mathrm{s}$ ) for $1,200 \mathrm{~s}$. After the austenization treatment, the steel box containing the austenitized samples was withdrawn from the muffle and the components were air-quenched to room temperature.

The air-quenched components were subjected to a subcritical heat treatment referred to as tempering. The tempering was performed in a similar way to that of the austenization treatment, i.e., the components were wrapped in a blick white sulphite drawing paper and put inside a steel box containing a mixture of $50 \% \mathrm{C}$ (graphite) and $50 \% \mathrm{Al}_{2} \mathrm{O}_{3}$ (aluminum oxide). The VSIs were double tempered at seven different temperatures, $100{ }^{\circ} \mathrm{C}, 200^{\circ} \mathrm{C}$, $300{ }^{\circ} \mathrm{C}, 400{ }^{\circ} \mathrm{C}, 500{ }^{\circ} \mathrm{C}, 600{ }^{\circ} \mathrm{C}$ and $700{ }^{\circ} \mathrm{C}$ for one hour each, respectively. Each component was heated to a specified temperature, held for one hour at this temperature, and then cooled in air. This process was repeated twice for each component at the specified temperature.

All heat treated VSIs were continuously cooled. Therefore, it was possible to use continuous cooling transformation (C.C.T.) diagrams found in the literature to predict the microstructural transformations. An isothermal transformation (I.T.) diagram ${ }^{37}$ for AISI M3:2 HSS was used because no C.C.T. diagram was found for this specific steel. According to Totten ${ }^{32}$ such consideration can be made, as he stated: "When comparing the curves for the start of transformation in C.C.T. and I.T diagrams for the same heat and steel grade, we found that in the C.C.T. diagram the curves are slightly shifted to longer times and lower temperatures". Both C.C.T. diagrams ${ }^{38}$ for AISI M2 HSS and AISI D2 tool steels have an unusual form of representation of the transformation line.

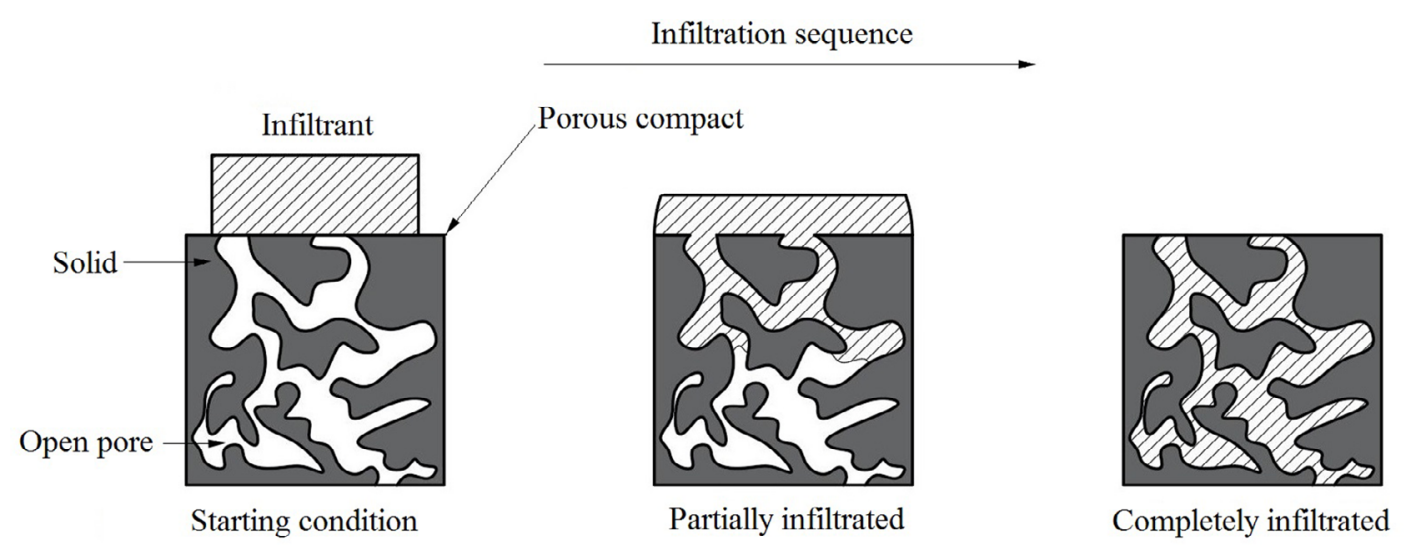

Figure 2. A sketch of the metallic infiltration process where capillary forces pull a metal melted into the open pores of a sintered compact $^{34}$ 
The $\mathrm{x}$-axis is not a simple plot of time and, therefore, cooling curves are not superimposed over the diagrams. Instead, the $\mathrm{x}$-axis plots the time required to cool the workpiece from $800^{\circ} \mathrm{C}$ to $500^{\circ} \mathrm{C}$, which is related to the cooling rate. Due to this manner of graphical representation, the microstructural transformation is given along vertical lines rather than the usual superimposed cooling curves. In addition, as a result of this vertical lines construction, it is possible to plot the hardness at room temperature as a function of the "halfcooling" time with a single curve ${ }^{46}$.

The mechanical and physical properties of the components were determined by three main techniques. First, the apparent hardness of all heat treated VSI was determined in accordance with the ASTM E 10-01 standard ${ }^{39}$. This method covers the determination of the Brinell hardness of metallic materials. For such, it was used a durometer made by Süssen - Wolpert model Testor HT1A with a tungsten carbide sphere of $\varnothing 2.5 \mathrm{~mm}$. A load of $187.5 \mathrm{kgf}$ was applied for a dwell time of $15 \mathrm{~s}$ for each measurement. Secondly, the as-sintered densities were determined by the Archimedes method, by immersing the inserts into deionized water, and measuring the difference between its humid, immersed and dry mass. This test was performed in accordance with the ASTM C 373-88 standard $^{40}$ and the different masses were obtained using an Ohaus analytical balance model Adventurer Pro AV264. Thirdly, the crush radial strength (CRS) test was performed in agreement with the MPIF 35 standard $^{41}$. This standard test involves radially compressing the VSI until its first crack appears.

Chemical composition analyses were carried out by two techniques, gas analysis and X-ray fluorescence spectrometry. A gas analyzer equipment (Leco CS-400) determined the carbon and sulfur content within the samples. The apparatus used an induction furnace and measured the amount of each element by infrared absorption ${ }^{42}$. The other elements were determined using a Shimadzu energy dispersive X-ray fluorescence spectrometer (EDXRFS) ${ }^{43-45}$ model EDX-720. The analyses were performed with X-ray potentials from light and heavy elements. The software employed was capable of performing a quantitative analysis from both spectrums.

The development of a set of desirable mechanical properties for a component often results from a phase transformation diagram that is dictated by heat treatment ${ }^{38}$. In the present work, the austenitic transformation during air-cooling occurred over a range of temperatures rather than at a single constant temperature. Therefore, the final microstructure was a mixture of continuously cooled transformation products ${ }^{46}$.

The samples were cold mounted using a resin mixture and polished through standard metallographic techniques. The samples were etched with Nital $3 \%$ (97\% ethyl alcohol $+3 \%$ concentrated $\mathrm{HNO}_{3}$ ) for $5 \mathrm{~s}^{47}$ prior to being examined under a light optical microscope (OM). For the scanning electron microscopy (SEM) and energy dispersive spectroscopy (EDS) analyses, the samples were over etched for $50 \mathrm{~s}^{48}$. The
OM was used to observe the grain structure, its shape and second phases present in the microstructure. The SEM was used in the backscattered electrons (BSE) detection mode and an EDS detector was used to identify which elements were present in the microstructures of the VSIs.

\section{Results and Discussion}

The Brinell apparent hardness (HB 2.5 / 187.5) variation of the as sintered and heat treated VSIs is shown in Fig. 3.

Considerable variations in the apparent hardness values of the components can be observed. According to the VSI final commercial requirements, the apparent hardness should be between $370 \mathrm{HB}$ and $410 \mathrm{HB}$ (2.5 / 187.5). Fig. 3 shows that the alloy and the heat treatment that resulted in apparent hardness between the desired hardness value is Alloy 1 (AISI M3:2 mixture) and Alloy 2 (AISI M2 mixture) double tempered at $600{ }^{\circ} \mathrm{C}$, and Alloy 3 (AISI D2 mixture) double tempered at $500{ }^{\circ} \mathrm{C}$. Hence, it is worth mentioning that all the following given results and discussion focused on these alloys and heat treatments.

The apparent hardness is a very important mechanical property. Other physical properties intrinsically related to mechanical property are the relative density and the crush radial strength (CRS) of a component. These are the main properties of the VSI and had already been studied by other authors such as Salgado et al. ${ }^{49}$ and Jesus Filho et al. ${ }^{2,9}$. A summary of the mechanical and physical properties of the heat-treated alloys is given in Table 3.

Regarding the work developed by Jesus Filho ${ }^{37}$ where the as-sintered VSI was analyzed, the mean relative density and CRS, $7.33 \mathrm{~g} / \mathrm{cm}^{3}$ and 1,268 MPa, were higher when compared to $7.2 \mathrm{~g} / \mathrm{cm}^{3}$ and $997 \mathrm{MPa}$ of Alloy 1, respectively. On the other hand, the apparent hardness obtained in the previous work, $380 \pm 25 \mathrm{HB}$, was lower than the one measured in

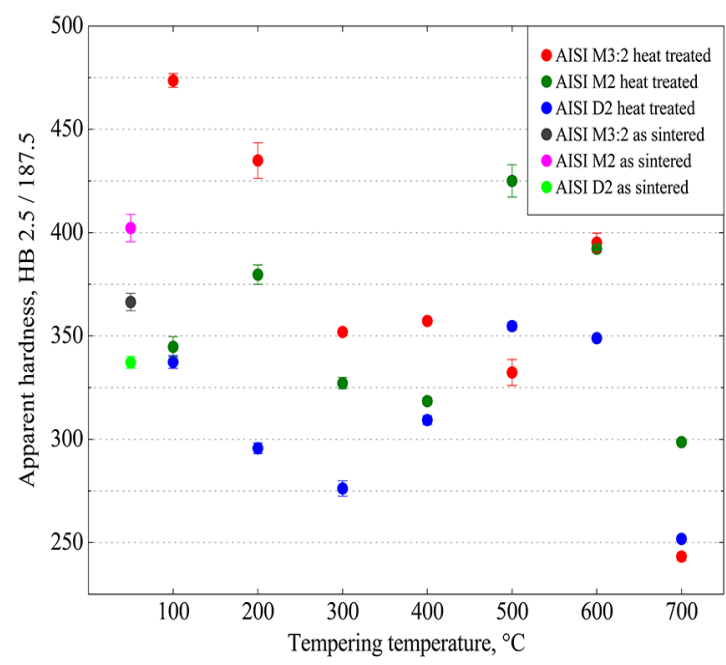

Figure 3. Variation of the Brinell apparent hardness (HB 2.5 / 187.5) for the three powder mixtures of VSI as sintered, quenched $\left(1,150{ }^{\circ} \mathrm{C}\right.$ quenched in air) and double tempered at seven different temperatures. 
Table 3. Mechanical and physical properties of the VSIs obtained with Alloy 1 (AISI M3:2 powder mixture), Alloy 2 (AISI M2 powder mixture) and Alloy 3 (AISI D2 powder mixture) air quenched and double tempered at $600{ }^{\circ} \mathrm{C}, 600{ }^{\circ} \mathrm{C}$ and $500{ }^{\circ} \mathrm{C}$, respectively

\begin{tabular}{lccc}
\hline Component & $\begin{array}{c}\text { Relative } \\
\text { density, g/ } \\
\text { cm3 }\end{array}$ & $\begin{array}{c}\text { Apparent } \\
\text { hardness, } \\
\text { HB 2.5/ } \\
\mathbf{1 8 7 . 5}\end{array}$ & $\begin{array}{c}\text { Crush radial } \\
\text { strength, } \\
\text { MPa }\end{array}$ \\
\hline Alloy 1 & $7.2 \pm 0.3$ & $395 \pm 5$ & $997 \pm 30$ \\
Alloy 2 & $7.4 \pm 0.3$ & $392 \pm 1$ & $579 \pm 92$ \\
Alloy 3 & $7.3 \pm 0.1$ & $355 \pm 2$ & $792 \pm 57$ \\
\hline
\end{tabular}

the present work, $395 \pm 5 \mathrm{HB}$. In comparison with the work developed previously by Santos et al. ${ }^{50-52}$, who considered only as-sintered components, the relative density can be considered to be the same, $7.4 \mathrm{~g} / \mathrm{cm}^{3}$ and $7.3 \mathrm{~g} / \mathrm{cm}^{3}$, for Alloy 2 and Alloy 3, respectively. The apparent hardness values measured by Santos ${ }^{50}$ was lower, $345 \pm 21 \mathrm{HB}$ and $325 \pm$ $22 \mathrm{HB}$, than the ones obtained in the present work, $392 \pm 1$ $\mathrm{HB}$ and $355 \pm 2 \mathrm{HB}$, for Alloy 2 and Alloy 3, respectively. The CRS values obtained by Santos ${ }^{50}$ was higher, $595 \pm 48$ $\mathrm{MPa}$ and $945 \pm 81 \mathrm{MPa}$, than those measured in the present work, $579 \pm 92 \mathrm{MPa}$ and $792 \pm 57 \mathrm{MPa}$, for Alloy 2 and Alloy 3, respectively. A correlation between some properties of the VSI obtained with the three different alloys can be observed. Such relationships are that the higher the apparent hardness measurements, the CRS values tend to be lower. This is justifiable since increases in tensile strength tend to lead to decrease in ductility ${ }^{53}$. Although the CRS values are lower when compared to the work developed by Santos ${ }^{50}$, this property is only necessary when assembling the VSI into the engine block. Therefore, there is no minimum level required for the CRS; the component just needs to withstand the assembly step.

The measured chemical composition of the VSI is shown in Table 4. The carbon and sulfur contents were determined by the gas analysis method. All the other elements were determined using energy dispersive of X-ray fluorescence spectrometry (EDXRFS).

From the results shown in Table 4, a higher amount and considerable variation in copper concentration in each alloy (as shown in Table 1) can be noticed when compared with the nominal value. Such concentrations should be $10 \%$ but the measured values ranged from $11.79 \%$ to $15.04 \%$. It can be related to the fact that during the compaction process of the iron powder mixtures and copper, there was a slight variation in the VSI and $\mathrm{Cu}$ mass that was added to the matrix cavity. Thus, the amount of copper should be ten percent of the insert mass, i.e., the insert and the $\mathrm{Cu}$ ring should be precisely paired.

During air quenching of the studied VSI, the cooling rate was measured with a thermocouple type $\mathrm{k}$ attached to the sample and to a data acquisition system. The obtained value was $0.6{ }^{\circ} \mathrm{C} / \mathrm{s}$.

The obtained cooling rates were superimposed over the C.C.T. and I.T. diagrams as a dash-dot line. It can be inferred that only martensite resulted from austenite transformation for Alloy 1 (Fig. 4a) and Alloy 2 (Fig. 4b). With respect to the transformation diagram for Alloy 3 (Fig. 4c), it can be seen that martensite and bainite will result from the austenite. Furthermore, in each alloy, other different microstructures were found due to the addition of other elements besides those of high-speed and tool steels, i.e., iron, $\mathrm{MnS}, \mathrm{NbC}$, graphite and so on.

Fig. 5a shows the optical micrograph of Alloy 1. Even though this alloy had the highest powder particle size (Table 1) and porosity (Table 3 ) compared to Alloy 2 and Alloy 3, which tends to decrease the components final properties, Alloy 1 was the one that showed the best results with respect to apparent hardness and CRS. This is because the AISI M3:2 HSS powder has the best mechanical properties when compared with the other steel powders studied. Such combination of heat treatment and powder mixtures resulted in fine copper distribution (almost white phase) and the presence of high amounts of

Table 4. Chemical composition of the VSI determined by gas analysis and energy dispersive X-ray fluorescence spectrometry. The carbon and sulfur amounts were determined using the first technique

\begin{tabular}{|c|c|c|c|}
\hline Element & Alloy 1, mass \% & Alloy 2, mass \% & Alloy 3, mass \% \\
\hline $\mathrm{Fe}$ & $75.74 \pm 0.12$ & $73.52 \pm 0.02$ & $77.56 \pm 0.02$ \\
\hline $\mathrm{Cu}$ & $12.54 \pm 0.05$ & $15.04 \pm 0.01$ & $11.79 \pm 0.02$ \\
\hline Mo & $2.87 \pm 0.01$ & $2.77 \pm 0.01$ & $0.52 \pm 0.01$ \\
\hline W & $1.97 \pm 0.02$ & $1.62 \pm 0.01$ & - \\
\hline $\mathrm{Cr}$ & $1.83 \pm 0.01$ & $2.09 \pm 0.01$ & $5.71 \pm 0.01$ \\
\hline $\mathrm{Nb}$ & $1.68 \pm 0.01$ & $2.03 \pm 0.03$ & $1.63 \pm 0.01$ \\
\hline V & $1.21 \pm 0.01$ & $0.79 \pm 0.01$ & $0.45 \pm 0.01$ \\
\hline $\mathrm{C}$ & $1.03 \pm 0.02$ & $0.97 \pm 0.03$ & $1.45 \pm 0.03$ \\
\hline $\mathrm{Mn}$ & $0.73 \pm 0.06$ & $0.78 \pm 0.06$ & $0.52 \pm 0.01$ \\
\hline $\mathrm{Si}$ & $0.29 \pm 0.12$ & $0.27 \pm 0.07$ & $0.27 \pm 0.02$ \\
\hline $\mathrm{S}$ & $0.11 \pm 0.03$ & $0.12 \pm 0.02$ & $0.10 \pm 0.02$ \\
\hline
\end{tabular}




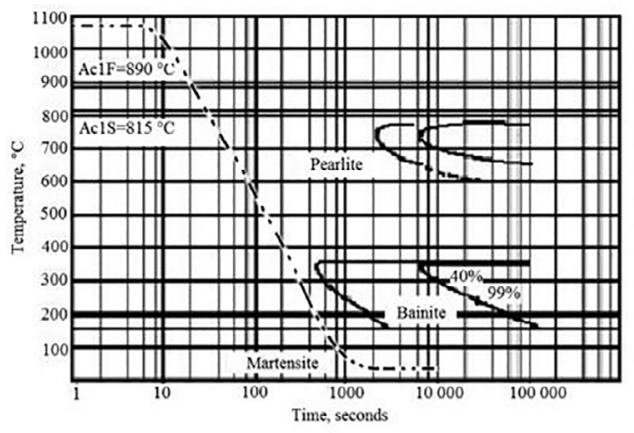

a)

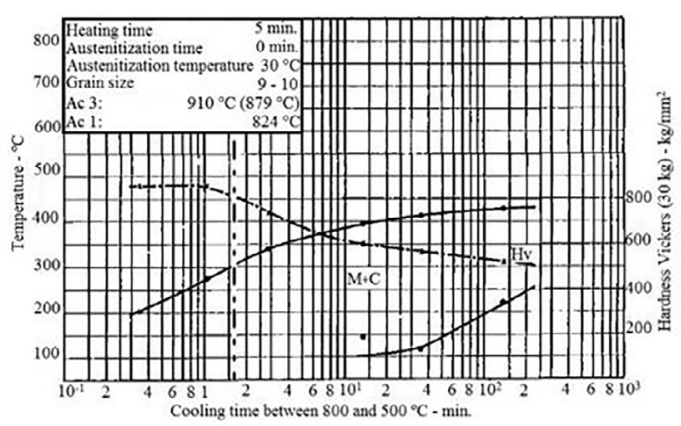

b)

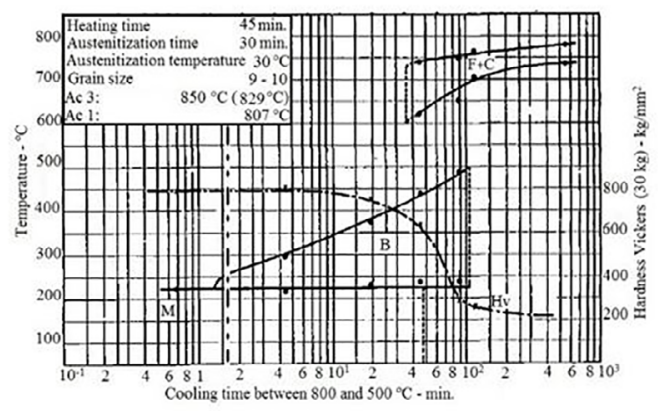

c)

Figure 4. a) Isothermal transformation (I.T.) diagram for AISI M3:2 $2^{37} \mathrm{HSS}$, continuous cooling transformation diagram (C.C.T.) for b) AISI M2 HSS, and c) AISI D2 ${ }^{46}$ tool steel.

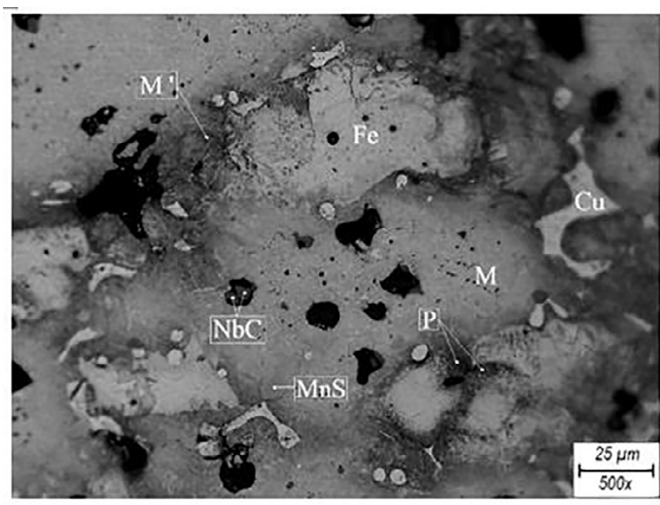

a)

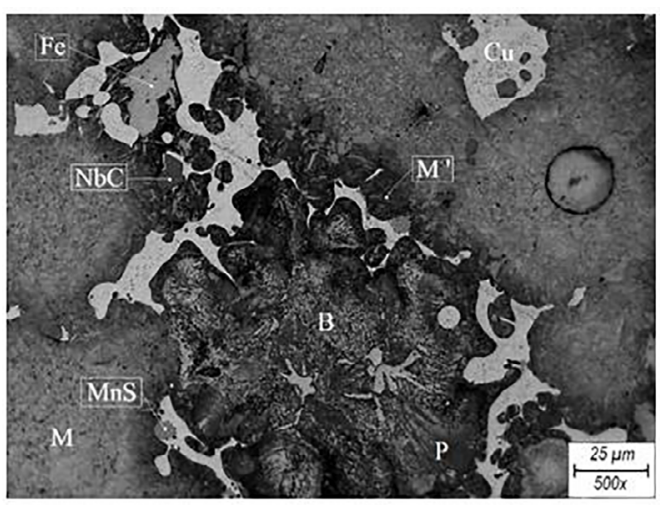

b)

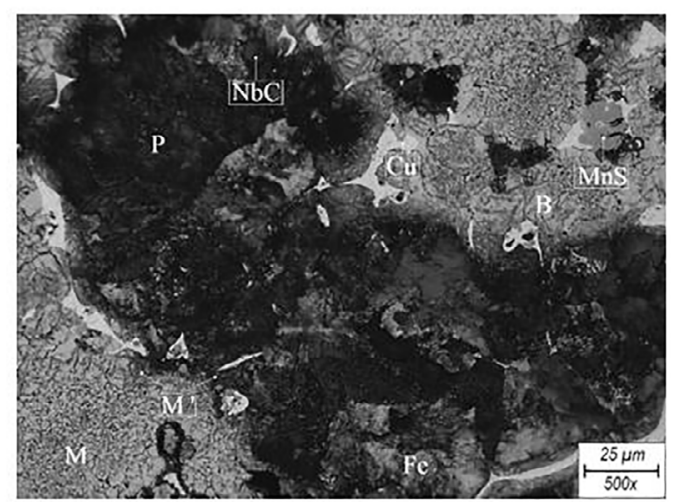

c)

Figure 5. Optical micrographs of a) Alloy 1 (AISI M3:2 mixture) and b) Alloy 2 (AISI M2 mixture) air quenched and double tempered at $600^{\circ} \mathrm{C}$, and c) Alloy 3 (AISI D2 mixture) air quenched and double tempered at $500{ }^{\circ} \mathrm{C}$. 
martensite (M, light gray). Also there was a contribution of the amount of carbon available (graphite added element) over the whole VSI microstructure. Further, a delayed austenite transformation into other phases due to insufficient time and temperature during heat treatment resulted in the formation of almost non-transformed ferrite islands (very light gray phase identified in the present work by Fe). A low quantity of martensite having a high content of carbon (M', gray) and perlite (P, dark gray) was observed. In addition, it was possible to identify the presence of manganese sulfide (MnS, medium gray), niobium carbide ( $\mathrm{NbC}$, very dark grey), and pores (black). As can be observed in Fig. 5b and EDXRFS chemical results (see Table 4), Alloy 2 had a higher copper concentration than the other two alloys. This tends to make the matrix more ductile. Also from Table 4, it can be seen that Alloy 2 has the highest $\mathrm{Nb}$ concentration. Araujo Filho et al. ${ }^{54}$ and Wentzcovithch et al. ${ }^{55}$ used niobium for increasing VSI apparent hardness, but on the other hand, this element tends to reduce the toughness of the component ${ }^{28}$. Therefore, the higher $\mathrm{Cu}$ and $\mathrm{Nb}$ concentration in Alloy 2 contributed to the lowest performance of this component with respect to CRS (Table 3). On the other hand, several properties had an important role in the good results exhibited by Alloy 2 . Such properties are low powder particle size distribution (the lowest), the formation of high volume fraction of martensite, and the formation of low amounts of pearlite, bainite (B,

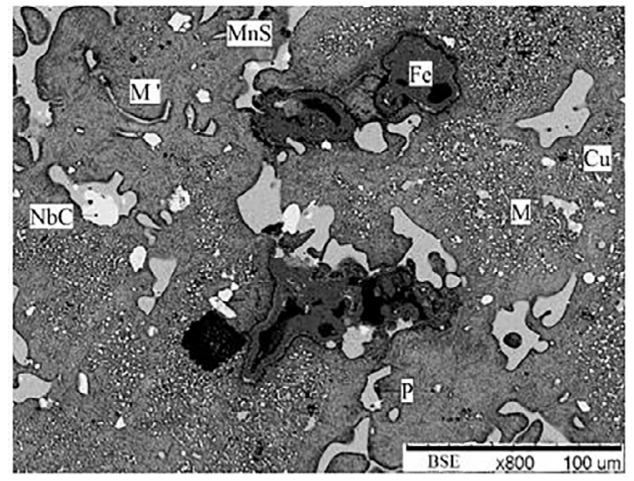

a)

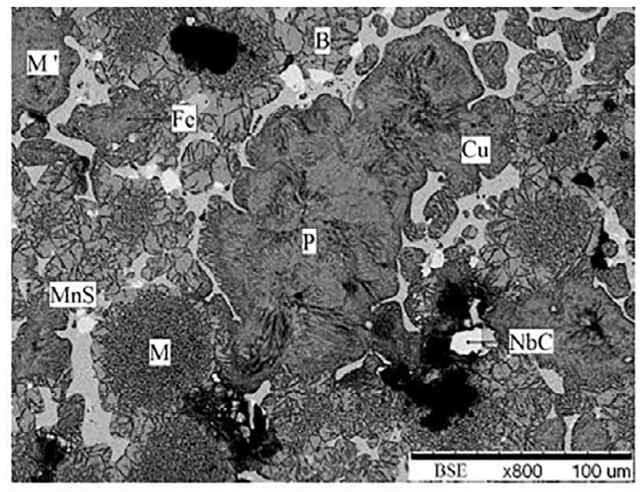

c)

Figure 6. SEM micrograph with elemental identification using EDS of: a) Alloy 1 (AISI M3:2 mixture), b) Alloy 2 (AISI M2 mixture) air quenched and double tempered at $600{ }^{\circ} \mathrm{C}$ and c) Alloy 3 (AISI D2mixture) air quenched and double tempered at $500{ }^{\circ} \mathrm{C}$. medium dark gray) and ferrite amounts due to the fast austenite transformation. From Fig. 5c, it can be concluded that Alloy 3 (AISI D2 tool steel mixture) had been the one with the fastest diffusion rate because the micrograph shows an entire transformation from austenite into pearlite when compared with the other two alloys. This high diffusion rate resulted in low mechanical properties for Alloy 3, in fact Alloy 3 exhibited the lowest mechanical properties when compared with those of Alloy 1 and Alloy 2. Thus, the high diffusion rate had a negative impact. However, the high relative density (which was the highest for Alloy 3 as shown in Table 3 ) and a fine copper distribution improved the CRS of the component.

From the optical micrographs, a correlation between the apparent hardness values and the microstructures of the VSIs can be made. The hardness values of Alloy 1 and 2 were very close. Even though Alloy 1 presented a more martensitic structure, it had a higher amount of ferrite in comparison to Alloy 2. On the other hand, Alloy 2 showed a lower quantity of ferrite but this alloy was rich in the bainite phase (B) that has a lower hardness value when compared to martensite. Alloy 3 had a huge amount of upper bainite (B'), which in turn have lower levels of hardness than the lower bainite or simply bainite phase.

Fig. 6 shows the elemental distribution in the microstructures of the three alloys after heat treatment by SEM with elements

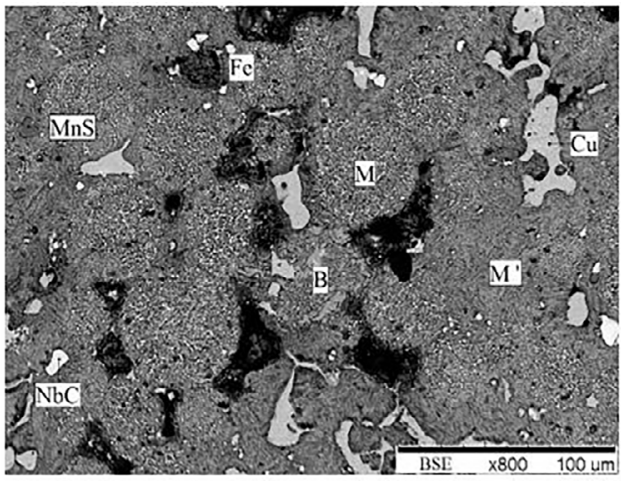

b) 
identified by EDS. In all cases, it was necessary to over etch the samples to discern between the HSS and the iron because both were added in similar amounts (see Table 1) and each one reacts in a different way in the same etchant. Due to over etching, phases such as bainite (B, light gray), pearlite ( $\mathrm{P}$, medium gray), ferrite ( $\mathrm{Fe}$, gray) and martensite having a high carbon content (M', dark gray) seem to be corroded. Niobium carbide ( $\mathrm{NbC}$, white) and manganese sulfide ( $\mathrm{MnS}$, very dark gray) can be easily distinguished in the microstructure. In all alloys, the martensite (M, medium dark grey) was generated from the austenite present in the HSS transformation (see Fig. 4), i.e., no martensite originated from the iron powder transformation even with the addition of other elements such as graphite. In Fig. 6a, it is possible to observe the oxidation of ferrite, which was probably due to water percolation into the pores (black). The overall microstructure appeared to be more heterogeneous compared to those of the other alloys as can be seen from the BSE contrast. In addition, it is possible to observe the distribution of coarse carbides as small points. Bainite formation was not observed in Alloy 1. An apparent lower amount of copper ( $\mathrm{Cu}$, very light gray) can be seen in Fig. 6b. Alloy 2 (as shown in Table 4) has the highest copper concentration, $15.04 \%$ against $12.54 \%$ (Alloy 1 ) and $11.79 \%$ (Alloy 3), which may be attributed to a particular region of the sample. The spherical shape of the AISI M2 HSS particles as stated in Table 1 can also be observed. A few amount of iron particles was transformed into ferrite. From the heat treatment process, mainly bainite was formed from the transformation of the iron particles. The formation of pearlite was not observed at the analyzed area. It was the most homogeneous microstructure from the three alloys examined in this study. In Fig. 6c, a very well defined bainite formation on the AISI D2 tool steel grain boundaries can be observed. This is in accordance to the C.C.T. diagram shown in Fig. 4c, which was used to predict that a small amount of bainite would result from the austenite transformation during the heat treatment of Alloy 3. There was a deep diffusion of the tool steel carbides into the microstructure. Even with the use of EDS technique, it was not possible to detect the fine distribution of carbides as can be observed in the electron micrographs of the others. It is possible to observe the copper metallic infiltration in the grain boundaries. Copper infiltration played an important role because it filled the open pores, thus reducing the residual porosity of the components, which tends to reduce the mechanical and physical properties of the VSI.

\section{Conclusion}

The heat treatments proved to be efficient according to the variations in physical and mechanical properties and microstructural evolution of the components.
It can be concluded from the results of the mechanical properties that the higher the apparent hardness of the VSI, the lower the crush radial strength.

Although the components obtained with AISI D2 tool steel (Alloy 3) exhibited the lowest mechanical and physical properties, it meets the minimum requirements by the automakers and deserves to be tested in an engine due to its lower cost compared with the other two powder mixtures.

The components obtained with the addition of AISI M3:2 (Alloy 1) and AISI M2 (Alloy 2) high-speed steels powders seem to be the most consistent ones regarding the VSI apparent hardness.

Even though there are many different phases present in the VSI microstructure, the added high-speed steel powder properties proved to have the highest influence on it.

\section{Acknowlodgments}

The authors want to thank CAPES and CNPq for the financial support. In addition, General Motors of Brazil, Höganäs and Group Combustol \& Metalpó are also acknowledged for materials and equipment supply.

\section{References}

1. Chang I, Zhao Y, eds. Advances in Powder Metallurgy: Properties, Processing and Applications. Sawston: Woodhead Publishing; 2013.

2. Jesus Filho ES, Jesus ERB, Salgado L, Jesus SL, Colosio MA, Santos JC, et al. Sintered Valve Seat Inserts - Microstructural Characterization. Materials Science Forum. 2006;530-531:6570 .

3. Fujitsuka H, Kawata H, Oyanagi M, Miyazawa T, Fujiki A. The Development of a Cobalt-Free Exhaust Valve Seat Insert. SAE Technical Paper 2004-01-0502; 2004. DOI: https://doi. org/10.4271/2004-01-0502

4. Sakai M. Self Lubrication Type P/M Materials for the Lead Free Valve Seat. SAE Technical Paper 2000-01-0395; 2000. DOI: https://doi.org/10.4271/2000-01-0395

5. Santos IP, Rossi JL. Processing and Characterization of Sintered Steel for Use in Valve Seat Inserts. In: Proceedings of the $21^{\circ}$ Congresso Brasileiro de Engenharia e Ciências dos Materiais; 2014 Nov 9-13; Cuiabá, MT, Brazil. p. 4366-4373. (In Portuguese).

6. Dalal K, Krueger G, Todsen U, Hannover FH, Nadkarni A. Dispersion Strengthened Copper Valve Seat Inserts and Guides in Automotive Engines. SAE Technical Paper 980327; 1998. DOI: https://doi.org/10.4271/980327

7. Kano M, Suzuki K, Matsuyama H, Sato S, Yamaguchi M, Ninomiya R, et al. New Copper Alloy Powder for Laser-Clad Valve Seat Used in Aluminum Cylinder Heads. SAE Technical Paper 2000-01-0396; 2000. DOI: https://doi.org/10.4271/200001-0396 
8. American Society for Metals (ASM). ASM Metals Reference Book: A handbook of data about metals and metalworking. Metals Park: ASM International; 1981.

9. Jesus Filho ES, Salgado L, Jesus SL, Rossi JL, Colosio MA, Santos JC. Machining and Mechanical Characterization of PM Materials for Valve Seat Inserts. Materials Science Forum. 2005;498-489:79-85.

10. Ding Z, Han J, Yang HD. Research on Wear Surface Morphology of PCBN Tools in High-Speed Machining Valve Seat Insert. Materials Science Forum. 2014;800-801:155-159.

11. Grupo Setorial de Metalurgia do Pó. A metalurgia do pó: alternativa econômica com menor impacto ambiental. São Paulo: Metallum Eventos Técnicos; 2009.

12. Duan CF, Li W, Zhang JL. Simulation Study on Heat Transfer Performance of Engine Exhaust Valve. Advanced Materials Research. 2012;591-593:639-643.

13. Brabec P, Dittrich A. The Simulation Calculation of Temperatures on Valve Seats of Combustion Engine and its Verification. Advanced Materials Research. 2014;1016:577-581.

14. Whittaker D. The PM structural parts industry - past growth and future prospects. Metal Powder Report. 1999;54(12):14-21.

15. Whittaker D. Process economic and technological advances in $\mathrm{P} / \mathrm{M}$ automotive part production. International Journal of Powder Metallurgy. 1998;34(4):53-62.

16. Myers K. Hard-Wearing Iron-Base Alloy is Soft on the Pocket. Materials World. 1999;7(12):755-756.

17. Kawata H, Hayashi K, Ishii K, Maki K, Ehira A, Toriumi M. The Development of a High-Speed Steel Based Sintered Material for High Performance Exhaust Valve Seat Inserts. SAE Technical Paper 980328; 1998. DOI: https://doi.org/10.4271/980328

18. Sato K, Midorikawa T, Takahashi T, Oshige H. Development of Valve Seat Material for Gas-Fueled Engines. SAE Technical Paper 2000-01-0911; 2000. DOI: https://doi.org/10.4271/200001-0911

19. Hayashi K, Aoki Y. The Development of Sintered Materials Containing Dispersed Die Steel Hard Particles for Intake Valve Seat Inserts. SAE Technical Paper 2001-01-0396; 2001. DOI: https://doi.org/10.4271/2001-01-0396

20. Ando K, Manabe A, Yasuda A. Hardfaced Valve and P/M Valve Seat System for CNG and LPG Fuel Engines. SAE Technical Paper 2005-01-0718; 2005. DOI: https://doi.org/10.4271/200501-0718

21. Kawata H, Maki K. Development of High Performance Valve Seat Insert Materials for Heavy-duty Engines. SAE Technical Paper 2006-01-0394; 2006. DOI: https://doi.org/10.4271/200601-0394

22. Grevnov LM. Heat treatment of sintered porous steels. Powder Metallurgy and Metal Ceramics. 1998;37(11-12):583-592.

23. Sobotová J, Kurík M, Cejp J. Influence of Heat Treatment Conditions on Properties of High-Speed P/M Steel Vanadis 30. Key Engineering Materials. 2015;647:17-22.

24. Mahaidin AA, Selamat MA, Manaf SA, Jaafar TR. Physical and Mechanical Properties of WC-Co Submicron Powders Using P/M Technique. Advanced Materials Research. 2014;879:12-15.
25. Bayer AM, Becherer BA. High-speed tool steels. In: ASM Handbook Committee. ASM Handbook. Volume 16: Machining. Materials Park: ASM International; 1989. p. 51-59.

26. Roberts G, Krauss G, Kennedy R. Tool Steels. 5th ed. Materials Park: ASM International; 1998.

27. Ericsson T. Principles of Heat Treating of Steels. In: ASM Handbook Committee. ASM Handbook, Volume 4: Heat Treating. Materials Park: ASM International; 1991. p. 14-30.

28. Chiaverini V. Tratamento Térmico das Ligas Metálicas. São Paulo: ABM; 2008.

29. Krauss G. Steels: Heat Treatment and Processing Principles. Materials Park: ASM International; 1990.

30. Liscic B, Tensi HM, Canale LCF, Totten GE. Quenching Theory and Technology. 2nd ed. Boca Raton: CRC Press; 2010.

31. German RM. Powder Metallurgy of Iron and Steel. New York: Wiley-Interscience; 1998.

32. Totten GE. Steel Heat Treatment: Metallurgy and Technologies. Boca Raton: CRC Press; 2006.

33. Iervolino F, Bulla L. Compactação. In: Grupo Setorial de Metalurgia do Pó. A metalurgia do pó: alternativa econômica com menor impacto ambiental. Cap. 7. São Paulo: Metallum Eventos Técnicos; 2009. p. 163-208.

34. German RM. Powder Metallurgy \& Particulate Materials Processing. Princeton: Metal Powder Industries Federation; 2005.

35. Group Combustol \& Metalpó. São Paulo, Brazil. Available from: $<$ http://www.combustol.com.br/conteudo.php?cod=10>. Access in: 02/06/2018.

36. Brazilian Association of Technical Standards (ABNT). ABNT NBR 6158:1995 - System of limits and fits - Procedure. São Paulo: ABNT; 1995. (In Portuguese).

37. Jesus Filho ES. Obtention, machining and wear of sintered alloys for automotive applications. [Thesis]. São Paulo: IPEN-USP; 2006. (In Portuguese).

38. Callister WD. Materials Science and Engineering: An Introduction. New York: John Wiley \& Sons; 2007. p. 325346.

39. ASTM International. ASTM E10-01 - Standard Test Method for Brinell Hardness of Metallic Materials. West Conshohocken: ASTM International; 2001.

40. ASTM International. ASTM C373-88 - Standard Test Method for Water Absorption, Bulk Density, Apparent Porosity and Apparent Specific Gravity of Fired Whiteware Products. West Conshohocken: ASTM International; 1999.

41. Metal Powder Industries Federation (MPIF). MPIF Standard 35 - Materials Standards for PM Structural Parts. Princeton: Metal Powder Industries Federation; 2009.

42. Moura SC, Coelho FP, Bustillos JOV. Characterization of carbon, sulfur and volatile compounds in nuclear fuel U3Si2Al. In: Proceedings of the International Nuclear Atlantic Conference; 2013 Nov 24-29; Recife, PE, Brazil. p. 1-5.

43. Cullity BD, Stock SR. Elements of X-ray Diffraction. Harlow: Pearson; 2014. 
44. Girolami GS. X-ray Crystallography. South Orange: University Science Books; 2016.

45. Warren BE. X-ray Diffraction. Mineola: Dover Publications; 1990.

46. Van der Voort GF. Atlas of Time-Temperature Diagrams for Iron and Steels. Materials Park: ASM International; 1991.

47. Colpaert H. Metalografia dos Produtos Siderúrgicos Comuns. São Paulo: Blucher; 2008.

48. Höganäs. Handbook for Sintered Components. Volume 6: Metallography. Höganäs: Höganäs AB; 2007.

49. Salgado L, Jesus Filho ES, Jesus ERB, Ambrozio Filho F, Rossi JL, Santos JA, et al. Mechanical and Microstructural Characterization of P/M High-Speed Steel Valve Seat Inserts. Materials Science Forum. 2003;416-418:312-316.

50. Santos IP. Processing and characterization of sintered steels for use in valve seat inserts. Dissertation. São Paulo: IPEN-USP; 2014. (In Portuguese).
51. Gomes MP, Santos I, Couto C, Mucsi C, Rossi JL, Colosio M. P/M Valve Seat Inserts: Air Quenching and Characterization. SAE Technical Paper 2017-01-5014; 2017. DOI: https://doi. org/10.4271/2017-01-5014

52. Gomes MP, Santos IP, Mucsi CS, Colosio MA, Rossi JL. Study of the mechanical and metallurgical properties of sintered steels for valve seat inserts application. In: Proceedings of the VII Encontro Científico de Física Aplicada; 2016 May 11-13; Serra, ES, Brazil. p. 59-61.

53. Brockenbrough RL, Merritt FS. Structural Steel Designer's Handbook. New York: McGraw-Hill; 2006.

54. Araujo Filho OO, Antonello RT, Gonzalez CH, Urtiga Filho SL, Ambrozio Filho F. Preparation of Molybdenum High-Speed Tool Steels with Addition of Niobium Carbide by Powder Metallurgy Techniques. Materials Science Forum. 2014;802:102-107.

55. Wentzcovitch A, Ambrozio Filho F, Silva LCE, Neves MDM. Sintering of AISI M2 high-speed steel with the addition of NbC. Materials Science Forum. 2012;727-728:90-95. 